\title{
3. Thick and Thin Citizenship as Measures of Australian Democracy
}

\author{
Kim Rubenstein ${ }^{1}$ and Niamh Lenagh-Maguire ${ }^{2}$
}

The importance of Australian citizenship can be obscured by its relatively sparse legal foundations, and by the omission of an expressly defined concept of citizenship from the Australian Constitution. However, one of the ways in which the legal status of citizenship is elevated beyond an empty label and given substance is the linking of citizenship with the structures of Australian democracy. This connection between a statutory label and Australia's constitutionally-mandated system of representative government also lends citizenship an important constitutional dimension that otherwise might be lacking. With limited exceptions, it is citizens who vote to elect governments at local, state and federal level, and in that sense these fundamental democratic mechanisms depend on a legal distinction between citizens and non-citizens. In turn, the connection between citizenship and the franchise adds critically important substance to the otherwise fairly bare notion of Australian citizenship as a legal category.

This chapter begins by examining the place of citizenship in Australia's democratic structure before moving on to examine the important High Court decision in Re MIMIA; ex parte Ame ('Ame'). ${ }^{3}$ We argue that the Court's approach to citizenship in that case reflects a narrow or 'thin' conception of democratic citizenship, tied predominantly to voting rights. Drawing upon the scholarship of US academic Linda Bosniak, this chapter outlines a fuller conception of citizenship, considering notions of rights, political participation and identity to argue that there is potential for Australians to hold a 'thicker' understanding of citizenship and providing an opportunity to expand the narrower judicial conception developed through the High Court's jurisprudence and conceptions of Australian democracy.

\footnotetext{
kim.rubenstein@anu.edu.au.

niamh.lenagh.maguire@gmail.com.

(2005) 222 CLR 439.
} 


\section{What kind of citizenship? Big 'C' or small 'c', thick or thin?}

A distinction is commonly drawn between the formal side of citizenship and its content or consequences (what Peter Schuck has described as 'what citizenship really means ${ }^{\prime 4}$ ). Understanding and accounting for the various dimensions of citizenship besides its formal, status-based element has been a consuming project for contemporary citizenship theory, particularly in the 60 years since the publication of TH Marshall's influential essay Citizenship and Social Class. ${ }^{5}$ Marshall identified three 'elements' of citizenship - the civil, political and social:

The civil element is composed of the rights necessary for individual freedom - liberty of the person; freedom of speech, thought and faith; the right to own property and to conclude valid contracts; and the right to justice ... By the political element I mean the right to participate in the exercise of political power, as a member of a body invested with political authority or as an elector of the members of such a body ... By the social element I mean the whole range from the right to a modicum of economic welfare and security to the right to share to the full in the social heritage and to live the life of a civilized being ... ${ }^{6}$

In Marshall's account, these elements had at one point been held simultaneously, but were 'unbundled' from citizenship during the Middle Ages and were only re-integrated into the concept gradually, beginning with civil rights in the 17th century, followed by political rights in the 18th century, and social rights in the 20th century.

The citizenship literature is replete with taxonomies of citizenship's substantive content, many of which owe an explicit debt to Marshall's pioneering categorisation of the elements of citizenship. Prominent examples include Joseph Carens's description of three dimensions of citizenship - legal, psychological and political — which he suggests are incompatible with a conception of the nation-state as a 'culturally homogenous form of political community in which citizenship is treated primarily as a legal status that is universal, equal and democratic'. ${ }^{7}$ Linda Bosniak's influential paper, 'Citizenship Denationalized', 8 describes four types of citizenship — citizenship as legal status, citizenship as

\footnotetext{
4 Peter Schuck, 'Citizenship in Federal Systems' (2000) 48 American Journal of Comparative Law 393. TH Marshall, Citizenship and Social Class: Class, Citizenship, and Social Development (New York, 1965). ibid 75.

7 Joseph Carens, Culture, Citizenship, and Community: A Contextual Exploration of Justice as Evenhandedness (2000) 161.

8 Linda Bosniak, 'Citizenship Denationalized' (2000) 7 Indiana Journal of Global Legal Studies 447.
} 
rights (following Marshall), citizenship as political participation, and citizenship as identity or solidarity, that is, 'the quality of belonging, the felt aspects of community membership' ${ }^{9}$ Changes in the composition of national communities and the relationship between individual citizens and the nation-state have also prompted further re-examinations of what it means to be a 'citizen' in a diverse, multicultural society such as Australia. This re-examination has occurred both in terms of the liberal democratic challenges described influentially by Will Kymlicka, ${ }^{10}$ and in the narrower sense of citizenship as a legal status that needs to adapt to the changing needs of those who hold it. ${ }^{11}$

As Kim Rubenstein explains, normative conceptions of citizenship are 'not only concerned with legal citizens, but with people and the way people should act and be treated as members of a community'. ${ }^{12}$ The Australian Citizenship Council distinguished between 'large- $\mathrm{C}$ ' and 'small-c' citizenship, to reflect this distinction between citizenship as a legal concept and its political, philosophical and social meanings. ${ }^{13}$ The latter conceptions of 'citizenship as desirable activity $^{\prime 14}$ tend to be based on membership and participation in a community, rather than legal status - the citizen is seen as 'a member of a political community, entitled to whatever prerogatives and encumbered with whatever responsibilities are attached to membership'. ${ }^{15}$

It is also important to recognise that there are connections between the legal and normative dimensions of citizenship. The status of the (large-C) Citizen is not simply a formality; citizenship carries with it a range of rights and obligations to participate in the life of the state that are denied to those who are not citizens. The legal status of Australian citizen is, in this respect, a 'gate-keeping' or exclusionary mechanism. Access to formal citizenship can determine whether a person can remain present in the Australian community and the extent to which a person can participate fully in Australian society. ${ }^{16}$

\footnotetext{
9 ibid 479.

10 Will Kymlicka, Multicultural Citizenship: A Liberal Theory of Minority Rights (Clarendon Press, 1995).

11 See for example Peter Spiro's work on citizenship in the context of global movement: Peter Spiro, 'Dual Citizenship as Human Right' (2010) 8 International Journal of Constitutional Law 111; Peter Spiro, 'Embracing Dual Nationality' in Randall Hansen and Patrick Weill (eds), Dual Nationality, Social Rights and Federal Citizenship in the US and Europe: the Reinvention of Citizenship (2001). For further discussion of the changing significance of Australian citizenship see Kim Rubenstein and Niamh Lenagh-Maguire, 'More or Less Secure?: Nationality Questions, Deportation and Dual Nationality' (Cambridge University Press, 2014) Kim Rubenstein and Niamh Lenagh-Maguire, 'Citizenship and the Boundaries of the Constitution' in Rosalind Dixon and Tom Ginsburg (eds), The Research Handbook in Comparative Constitutional Law (Edward Elgar, 2011).

12 Kim Rubenstein, Australian Citizenship Law in Context (Lawbook, 2002) 6.

13 Australian Citizenship Council, 'Australian Citizenship for a New Century' (Report, Australian Citizenship Council, 2000) 7.

14 Will Kymlicka and Wayne Norman, 'Return of the Citizen: A Survey of Recent Work on Citizenship Theory' (1994) 104 Ethics 352, 353.

15 Michael Walzer, 'Citizenship' in Terence Ball, James Farr and Russell Hanson (eds), Political Innovation and Conceptual Change (Cambridge University Press, 1989) 211.

16 See Migration Act 1958 (Cth) ss 14, 198.
} 
Looking beyond the technicalities of citizenship as a legal status can also be an attempt to develop a 'thick description' of what citizenship means as a social phenomenon, a political dynamic and, importantly, as a personal experience. The language of 'thick description' is in part an extrapolation from the approach to ethnography advocated by Clifford Geertz. ${ }^{17}$ Geertz describes ethnography as 'an elaborate venture in ... "thick description"'. ${ }^{18}$ Borrowing an example from Gilbert Ryle, from whom he also draws the language of 'thick' and 'thin' description, Geertz describes some of the different ways in which a seemingly simple act of constricting one eyelid, whether involuntarily or deliberately, so as to 'wink', carries social meaning:

[B]etween ... the 'thin description' of what the rehearse (parodist, winker, twitcher ...) is doing ('rapidly contracting his right eyelids') and the 'thick description' of what he is doing ('practicing a burlesque of a friend faking a wink to deceive an innocent into thinking a conspiracy is in motion') lies the object of ethnography: a stratified hierarchy of meaningful structures ... ${ }^{19}$

In a very different disciplinary setting, we argue that a focus on the formal aspects of citizenship, in particular on the allocation of the statutory label of 'citizen' and on the distribution of formal political rights like voting, generates a fairly thin or superficial understanding of what it means to be a citizen. While those legal and structural aspects of citizenship are critically important, they are not the whole story of a person's experience as a citizen.

\section{Australian citizenship as a legal status}

'Australian citizenship' is, on its face, a statutory rather than constitutional status. As we argue later in this chapter, the fact that so much of the legal architecture of Australian citizenship rests on an inherently malleable statutory foundation may contribute to its relative 'thinness' as a legal concept. As Kirby J explained in DJL $v$ Central Authority:

The Australian Constitution does not refer to the status of 'citizen' in relation to native born or naturalized people of the Commonwealth. The 'people' are referred to in several places. Elsewhere the people who are

17 Clifford Geertz, 'Thick Description: Toward an Interpretive Theory of Culture' in Clifford Geertz, The Interpretation of Cultures (Basic Books, 1973) 3.

18 ibid 6.

19 ibid 7. 
entitled to vote are described as 'electors'. In harmony with the notions of the time, the Constitution refers to the national status of Australians as that of 'a subject of the Queen' ${ }^{20}$

The word 'citizen' appears only once in the Australian Constitution, in a provision dealing with the disqualification of a 'citizen of a foreign power' from being elected to the Federal Parliament. ${ }^{21}$ While the Constitution does not include a definition of Australian citizenship, it does classify people according to other statuses - as 'subjects of the Queen', ${ }^{22}$ 'residents of a state' (reflecting the federal structure of the Commonwealth of Australia) $)^{23}$ and 'aliens' ${ }^{24}$

Prior to the creation of a statutory form of Australian citizenship in 1948, 'the major distinction of membership in Australia ... was between British subjects and aliens' ${ }^{\prime 25}$ A person born or naturalised in Australia was a British subject. ${ }^{26}$ Relying on its power to make laws with respect to 'naturalisation and aliens' (the aliens power), in 1948 the Federal Parliament enacted a statutory form of Australian citizenship. ${ }^{27}$ The Parliament has also relied on the aliens power to make laws dealing with the terms on which 'non-citizens' may enter and remain in Australia and the removal of 'unlawful non-citizens' ${ }^{28}$ The Australian Citizenship Act 2007 (Cth) (the Citizenship Act) currently determines who is entitled to Australian citizenship, including provisions for citizenship by descent and by naturalisation, but that Act is silent as to the rights and duties that flow from the status of 'Australian citizen'.

\section{The substance of citizenship in Australia: Democracy and voting rights}

The Australian Citizenship Act creates and confers the bare legal status of Australian citizenship. The Constitution, and other laws of the Commonwealth

\footnotetext{
20 (2000) 201 CLR 226, 277 (Kirby J).

21 Australian Constitution s 44.

22 ibid ss 34, 117.

23 ibid ss $25,75,117$.

24 ibid s 51(xix).

25 Rubenstein, above n 12, 47.

26 ibid 47-9.

27 See Naturalisation Act 1903-1920 (Cth); Nationality Act 1920 (Cth); Australian Citizenship Act 1948 (Cth); Australian Citizenship Act 2007 (Cth).

28 For an overview of migration legislation in Australia post-Federation, see Mary Crock, Immigration and Refugee Law in Australia (Federation Press, 1998); John Vrachnas, Kim Boyd et al., Migration and Refugee Law: Principles and Practice in Australia (Cambridge University Press, 2005) ch 2.
} 
and the States and Territories, give that status its legal substance. ${ }^{29}$ In this chapter we focus on the relationship between the status of citizen and Australia's democratic system of government.

Notwithstanding its omission from the Constitution, Australian citizenship has a constitutional dimension. In Chu Kheng Lim $v$ Minister for Immigration, Local Government and Ethnic Affairs, ${ }^{30}$ Gaudron J recognised that the statutory concept of citizenship is both constitutionally unnecessary and constitutionally useful:

Citizenship, so far as this country is concerned, is a concept which is entirely statutory, originating as recently as 1948. It is a concept which is and can be pressed into service for a number of constitutional purposes. But it is not a concept which is constitutionally necessary, which is immutable or which has some immutable core element ensuring its lasting relevance for constitutional purposes ... ${ }^{31}$

As we explain in this chapter, one of the ways in which the concept of citizenship is 'pressed into service' in a constitutional context is in determining who is entitled to take part in Australian democracy as an 'elector'.

\section{Statutory framework: The relationship between citizenship and the franchise}

The Constitution gives the Federal Parliament the power to make laws dealing with the qualification of electors. 'That Australia came to have universal adult suffrage was the result of legislative action. ${ }^{32}$ That legislative choice now has a constitutional dimension; as the High Court made clear most recently in Rowe $v$ Electoral Commissioner, ${ }^{33}$ the Parliament is not free to abandon universal suffrage. Subject to limited exceptions, Australian citizens are required to enrol as electors on the federal electoral roll and to cast votes at federal elections. ${ }^{34}$

This legislative choice reveals something of the connection between citizenship and the exercise of political rights in Australia, in particular the idea that a certain kind of connection with the Australian nation beyond, for example, mere presence in the community, is required before a person should be allowed to elect a national or sub-national government, and that citizenship carries with it important obligations to take an active part in the democratic process. In this

\footnotetext{
9 Rubenstein, above n 12, ch 5. 
way, the statutory status of citizen elevates a person's standing in the community above that of a long-term resident in a way that is not the case in many other areas of public life (taxation or employment rights, for example).

While the rule that an elector needs to be a citizen, and that a citizen is entitled to be an elector, tells us something about the substantive content of citizenship as a legal status, the exceptions to that rule also shed light on what it means to be a citizen. Here, we focus on two such exceptions - a category of noncitizens who are entitled to vote, and a category of citizens who are not. Turning to the first special category of exceptions, British subjects who were on the electoral roll immediately before 26 January 1984 continue to be entitled to enrolment under the Commonwealth Electoral Act. ${ }^{35}$ This is a class of long-term residents of the Australian community who do not possess statutory citizenship but who had been entitled to vote on the basis of their British subject status and satisfaction of a minimum six-month residence criterion. Australia's growing constitutional independence from the United Kingdom has meant that British subjecthood is legally and constitutionally distinct from Australian citizenship, so a British subject who settled in Australia after 1984 would not be entitled to vote (and, indeed, would be subject to laws made under the aliens power). ${ }^{36}$ The Parliament's choice to adopt citizenship as an essential criterion for the federal franchise and effectively to abandon qualification for non-citizens on the basis of a minimum period of residence, elevates the possession of formal citizenship over even very long-term membership of the Australian community. Something more than a long period of residence in Australia is required before a person should be entitled to vote; rather, this fundamental political right is reserved for those with a deeper, or at least more formal, connection with the Australian community. Maintaining a 'grandfathered' entitlement for British subjects resident in Australia before 1984 can be seen simply as a matter of fairness - having at one stage enjoyed one of the central rights of citizenship it would arguably be unfair to deprive this class of person of their right to vote. These arrangements can also be seen as a recognition of the particular historical resonance of 'British subject' status in Australia and a reminder of a time when 'British subject' status was worth as much as, if not more than, the status of 'Australian citizen'.

Of course it is also possible for an Australian citizen to lose the right to vote: if they are incapable of understanding the nature and significance of enrolment and voting, are convicted of treason or treachery or, more controversially, if

\footnotetext{
35 ibid.

36 Shaw v Minister for Immigration \& Multicultural Affairs (2003) 218 CLR 28; Re Patterson; Ex parte Taylor (2001) 207 CLR 391; Nolan v Minister for Immigration \& Ethnic Affairs (1988) 165 CLR 178.
} 
they are serving a sentence of imprisonment for three years or longer. There has seemingly been little argument about the first two of these grounds of disqualification. As Gleeson CJ put it in Roach v Electoral Commissioner, ${ }^{37}$

The rationale for excluding persons of unsound mind is obvious, although the application of the criterion of exclusion may be imprecise, and could be contentious in some cases. The rationale is related to the capacity to exercise choice. People who engage in acts of treason may be regarded as having no just claim to participate in the community's selfgovernance. ${ }^{38}$

The question whether prisoners ought to be allowed to vote has attracted more critical attention, and was considered by the High Court in 2007 in Roach. In that case, which Elisa Arcioni has considered in greater detail in this volume, the Court was asked to decide whether a law disenfranchising a person serving a prison sentence, irrespective of the length of their sentence, was constitutionally valid. The judgments in this case shed light on what it means to deprive a citizen of their right to vote, and on the critical importance of voting as one of the indicia of full civic membership. In considering the possible justifications of such a law, Gleeson CJ held that

the rationale for the exclusion must be that serious offending represents such a form of civic irresponsibility that it is appropriate for Parliament to mark such behaviour as anti-social and to direct that physical separation from the community will be accompanied by symbolic separation in the form of loss of a fundamental political right ... Serious offending may warrant temporary suspension of one of the rights of membership, that is, the right to vote.

His Honour had earlier reasoned:

It is consistent with our constitutional concept of choice by the people for Parliament to treat those who have been imprisoned for serious criminal offences as having suffered a temporary suspension of their connection with the community, reflected at the physical level in incarceration, and reflected also in temporary deprivation of the right to participate by voting in the political life of the community. It is also for Parliament, consistently with the rationale for exclusion, to decide the basis upon which to identify incarcerated offenders whose serious criminal wrongdoing warrants temporary suspension of a right of citizenship.

37 Roach (2007) 233 CLR 162, 182 (Gleeson CJ).

38 ibid, 179 (Gleeson CJ). 
The seriousness of a person's wrongdoing was a central consideration in the reasoning of the majority judges in Roach, who held invalid the blanket ban on prisoners voting but accepted that it would be valid to exclude prisoners serving sentences of at least three years. As the joint majority judgment of Gummow, Kirby and Crennan JJ observed:

[I]n the federal system established and maintained by the Constitution, the exercise of the franchise is the means by which those living under that system of government participate in the selection of both legislative chambers, as one of the people of the relevant State and as one of the people of the Commonwealth. In this way, the existence and exercise of the franchise reflects notions of citizenship and membership of the Australian federal body politic.

Such notions are not extinguished by the mere fact of imprisonment. Prisoners who are citizens and members of the Australian community remain so. Their interest in, and duty to, their society and its governance survives incarceration. Indeed, upon one view, the Constitution envisages their ongoing obligations to the body politic to which, in due course, the overwhelming majority of them will be returned following completion of their sentence. ${ }^{39}$

\section{A test case: Can 'real' citizenship exist without voting rights?}

In 2005, the High Court held in $A m e^{40}$ that Australian citizens born in Papua, who had held the legal status of citizen under the Australian Citizenship Act from the Act's inception in $1948^{41}$ until 1975, could have that status unilaterally stripped from them by regulations because that citizenship was not 'real'42 was only a 'technical' status ${ }^{43}$, was 'largely nominal'44 was 'not in fact or law full

\footnotetext{
39 ibid 199 (Gummow, Kirby, Crennan JJ).

40 (2005) 222 CLR 439.

41 Before that time Papuans were British subjects under the authority of the Commonwealth of Australian by Letters Patent and accepted as the Territory of Papua by s 5 of the Papua Act 1905 (Cth).

42 Re Minister for Immigration and Multicultural and Indigenous Affairs; Ex parte Ame (2005) 222 CLR 439,

449 (Gleeson CJ, McHugh, Gummow, Hayne, Callinan and Heydon JJ).

43 ibid.

44 ibid, 470 (Kirby J).
} 
or real citizenship', ${ }^{45}$ was a 'veneer of Australian citizenship', ${ }^{46}$ was a 'flawed citizenship', ${ }^{47}$ was of a 'fragile and strictly limited character', ${ }^{48}$ and was more like a 'shadow... of mere appearances and title' ${ }^{49}$

\section{Background: Papuan independence and loss of citizenship}

Papua was an Australian territory from 1906-1975. ${ }^{50}$ Until the introduction of a statutory Australian citizenship, both Australians and Papuans were formally British subjects. ${ }^{51}$ Under the Citizenship Act, 'Australia' was defined to include Norfolk Island and the Territory of Papua. A person born in Papua after the passage of the Citizenship Act was therefore born in Australia for the purposes of the Act and acquired the status of 'Australian citizen'.$^{52}$ However, the substantive rights attached to Papuans' citizenship were not equivalent to those enjoyed by other Australian citizens. Papua was not part of Australia for the purposes of the Migration Act 1958 (Cth) ('the Migration Act'), ${ }^{53}$ and its inhabitants were required to obtain a permit before entering mainland Australia, in contrast to the free right of entry enjoyed by most other Australian citizens. ${ }^{54}$

In 1975, Papua became part of the newly independent Papua New Guinea (PNG). The Papua New Guinea Constitution did not permit dual citizenship, and provided that a person who was 'a real foreign citizen' at the time that PNG became independent would not acquire citizenship of PNG. ${ }^{55}$ A person who held Australian citizenship but had no right to enter and reside in Australia did not have 'real foreign citizenship' for this purpose. ${ }^{56}$ In response, the Papua New Guinea Independence (Australian Citizenship) Regulations 1975 (Cth) ('the Independence Regulations') stripped Australian citizenship from anyone who became a PNG citizen at the date of PNG's independence (16 September 1975). ${ }^{57}$

\footnotetext{
45 ibid.

46 ibid, 474 (Kirby J).

47 ibid.

48 ibid 483 (Kirby J).

49 ibid.

50 Papua Act 1905 (Cth). Prior to Federation, the Colony of Queensland had attempted to annex Papua in order to provide a 'buffer' between it and German-controlled New Guinea: Richard Herr, 'Australia, Security and the Pacific Islands: From Empire to Commonwealth'(2006) 95 The Round Table 705, 707.

51 Ame (2005) 222 CLR 439, 467.

52 Nationality and Citizenship Act 1948 (Cth) s 10.

53 See Acts Interpretation Act 1901 (Cth) s 17.

54 Migration Act 1958 (Cth) ss 6-7. Counsel for the applicant submitted that the requirement that Papuans obtain an entry permit was based on a desire to exclude non-white inhabitants of Australian territory from the mainland: Transcript of Proceedings, Re MIMIA; Ex parte Ame (High Court of Australia, K Rubenstein, 3 March 2005).

55 Constitution of the Independent State of Papua New Guinea, ss 64-5.

56 ibid.

57 Papua New Guinea Independence (Australian Citizenship) Regulations 1975 (Cth).
} 
Thus, Papuans who had not obtained residence rights in Australia became PNG nationals under that country's new Constitution, and upon acquiring that status lost their Australian citizenship.

\section{Ame's case: What makes a 'real' citizen?}

A Papuan man, Amos Bode Ame, argued in the High Court in 2005 that the regulations which purported to take away his Australian citizenship could not validly apply to him, nor could the Migration Act restrict his right to enter and remain on the Australian mainland. ${ }^{58} \mathrm{Mr}$ Ame challenged the distinction between 'real' citizens and the residents of external territories, and asserted that the Commonwealth could not treat him as an immigrant or an alien when he sought to enter Australia, and could not unilaterally withdraw his citizenship.

The High Court held that Papuans had held a form of citizenship that was qualitatively different from other forms of Australian citizenship:

[I]t was no more than nominal citizenship, applicable for limited purposes ... It conferred few rights and specifically no rights freely to enter the States and internal territories of Australia, as other Australian citizens might do. Nor did it permit its holders to enjoy permanent residence in the States and internal territories ... ${ }^{59}$

Mr Ame's contention that he was a 'real' Australian citizen failed, on the basis that his was a 'hollow' form of citizenship which did not equate to the rights held by inhabitants of mainland Australia. The Court acknowledged the clear intention on the part of the Federal Parliament to restrict the rights afforded to Papuan-born Australian citizens, and held that

[t]he Constitution does not require that all inhabitants of all external territories acquired by Australia should have an unfettered right of entry into, and residence in, mainland Australia. There is no reason why Parliament cannot treat such an inhabitant as an immigrant. ${ }^{60}$

The High Court upheld the Commonwealth legislation that stripped Papuan Australians of their citizenship on the basis that the laws were validly made under the territories power. Section 122 of the Constitution gives the Commonwealth power to legislate 'for the government' of a Territory 'placed by the Queen under the authority of and accepted by the Commonwealth', of which Papua

58 Ame (2005) 222 CLR 439, 441-2.

59 ibid 471.

60 ibid 458 (Gleeson CJ, McHugh, Gummow, Hayne, Callinan and Heydon JJ). 
was an example. The High Court confirmed that the territories power allowed the Commonwealth to confer citizenship on the inhabitants of a territory, and conversely allowed that citizenship to be withdrawn:

Parliament is not obliged to confer Australian citizenship upon all inhabitants of all external territories. Furthermore, the powers under which it may legislate to confer such citizenship when a Territory is acquired enable Parliament to legislate to withdraw such citizenship when rights of sovereignty or rights of administration in respect of such Territory come to an end. ${ }^{61}$

As a consequence, Mr Ame could be deprived of his citizenship and thereafter treated as a non-citizen under the Migration Act. ${ }^{62}$

The Court felt compelled to use these characterisations devaluing the status of citizenship held by those Papuans because Papuan Australian citizens did not have a right to enter the mainland of Australia, ${ }^{63}$ or reside in mainland Australia, ${ }^{64}$ and Ame, '[a]lthough a citizen, had no right (still less a duty) to vote in Australian elections and referenda. He could perform no jury or other civic service in Australia'. ${ }^{65}$ Indeed, despite his status of a citizen, he and his fellow country-men and women were, to all intents and purposes 'treated as ... foreigner[s] ${ }^{.66}$

The language of the Court's decision strikingly resembles an infamous United States Supreme Court decision of almost 150 years earlier. In Dred Scott $v$ Sanford ${ }^{67}$ the Supreme Court held that an emancipated former slave was not a 'citizen of a State' entitled to invoke the Court's diversity jurisdiction under Article III of the US Constitution. The Court held that African slaves and their descendants, whether or not they had been emancipated,

are not included, and were not intended to be included, under the word 'citizens' in the Constitution, and can therefore claim none of the rights and privileges which that instrument provides for and secures to citizens of the United States. On the contrary, they were at that time considered as a subordinate and inferior class of beings who had been subjugated by the dominant race, and, whether emancipated or not, yet

61 ibid.

62 ibid 459.

63 ibid 449 (Gleeson CJ, McHugh, Gummow, Hayne, Callinan and Heydon JJ).

64 ibid 470 (Kirby J).

65 ibid 481 (Kirby J).

66 ibid.

6760 US 393 (1857). 
remained subject to their authority, and had no rights or privileges but such as those who held the power and the Government might choose to grant them. ${ }^{68}$

In part, the Court reached this conclusion because it was understood that citizens of a state were free to move about the country and enjoyed certain fundamental rights when in another state - a situation that simply did not apply as a matter of law to 'those persons who are the descendants of Africans who were imported into this country and sold as slaves' ${ }^{69}$

In Ame's case, the practical disjuncture between rights and status effectively enabled the High Court to affirm that as a matter of law someone could hold the legal status of citizen, without any claim to rights associated with that status. The High Court was able to deny Mr Ame's claim to Australian citizenship because the kind of citizenship he had once held was flimsy and lacking in many of the aspects of citizenship that typically lend it meaning and value. It was important to all of the judges that Papuans had held a form of Australian citizenship that was deficient in many formal, legal respects. Whilst the scope of the Federal Parliament's power with respect to external territories would, on its face, have remained the same, we can speculate that had Mr Ame and his compatriots been full and active citizens of Australia with the same rights of entry and residence as other Australians, or had they enjoyed rights of democratic participation in Australia, the Court might have been less willing to uphold the Parliament's effort to strip them of those rights.

\section{When citizenship lacks substance/depth}

In this final section, we consider Ame's case through the prism of Linda Bosniak's analysis of citizenship as a legal status, as a source of rights, as a form of political activity, and as an identity. As we noted at the beginning of this chapter, there are different ways in which citizenship is "pressed into service ${ }^{70}$ and these differences reflect the different ends to which the concept of citizenship is invoked. As Bosniak explains so thoughtfully in her article, 'Citizenship Denationalised', ${ }^{71}$ there are four different ways in which scholars write about citizenship. The first is 'citizenship as legal status', ${ }^{72}$ the second is 'citizenship

68 ibid 404-5.

69 ibid 403 .

70 This is the term used above by Justice Gaudron in Chu Kheng Lim v Minister for Immigration, Local Government and Ethnic Affairs (1992) 176 CLR 1, 54.

71 Linda Bosniak, 'Citizenship Denationalized' (2000) 7 Indiana Journal of Global Legal Studies 447.

72 ibid 456-63. 
as rights', ${ }^{73}$ the third is 'citizenship as political activity' ${ }^{74}$ and finally there is writing about 'citizenship as identity'.$^{75}$ Of course, some of the scholarship uses these terms in overlapping ways, but her distinctions are helpful in thinking through the way in which legal status sits with other conceptions of citizenship as rights, as political activity and as identity.

Citizenship as 'legal status' is what is important to the nation state. The legal status represents legal recognition of membership of an 'organized political community' ${ }^{76}$ The nation state determines who has that legal status, and debates - including those about automatic citizenship, acquisition of citizenship, rights to citizenship by descent, and indeed rights associated with change of territory and citizenship — revolve around this legal status. For the nation state, citizenship has been primarily about legal status. In Australia, the legal status of 'citizen' did not exist until 1949 and its scope has changed as Parliament so desired, through legislative amendment over time. Returning to Justice Gaudron's earlier cited statement in Lim, there has been no 'immutable core element[s] ensuring its lasting relevance for constitutional purposes' ${ }^{\prime 7}$ In contrast, for the new state of Papua New Guinea, there was a desire, from the experience of the shallow, formal status of the statutory version of their Australian citizenship to bestow upon the Papua New Guinea citizenship a status of constitutional value. There was a commitment to give citizenship 'real' meaning. Connected with this was a belief in Papua New Guinea that citizenship had to be singular. Both the joint judgment and Kirby J's separate opinion in Ame refer to the figurative language used in the Report of the Constitutional Planning Committee which was considering the preparation of the new PNG constitution: 'no man, it is said, can stand in more than one canoe' ${ }^{78}$ Accordingly, dual citizenship was constitutionally prohibited. If a person was a Papua New Guinean citizen, then they could not also be an Australian citizen.

For Mr Ame, and those like him born in Australian territory, that legal status at birth was significant. Holding that legal status meant something to them. They held a belief that there would be rights associated with that status. Indeed, this leads us to Bosniak's second characterization of 'citizenship as rights'. Echoing the work of TH Marshall referred to earlier in this chapter, Bosniak argues:

In twentieth century social theory, the notion of citizenship has been most closely associated with the enjoyment of certain important rights and entitlements. In this conception of citizenship, the enjoyment of 
rights is the defining feature of societal membership: citizenship requires the possession of rights, and those who possess the rights are usually presumed thereby to enjoy citizenship. ${ }^{79}$

However, this approach to citizenship highlights exclusion and second-class citizenship, 'and the ways that racial subordination has painfully distorted formally egalitarian polities' ${ }^{80}$ This is indeed what happened in Australia, both in relation to its own Indigenous peoples ${ }^{81}$ and in the experience of Papuan citizens upon PNG independence. Australia did not create an equal or egalitarian status of Australian citizen - different citizens had different rights and the Papuan Australian citizens felt the legacy of that profoundly. So much so that in creating a new Papua New Guinea state, there was an overt desire to distinguish itself from Australia to ensure a full and equal Papua New Guinean status of citizen. ${ }^{82}$

Moreover, it was the fact that different 'rights' were accorded to some Australian citizens as opposed to others that became relevant to the High Court's decision to deny the claim to Australian citizenship status by $\mathrm{Mr}$ Ame. Indeed, it is the next category of citizenship that Bosniak refers to that was fatal to $\mathrm{Mr}$ Ame's claim. Bosniak separates 'citizenship as political activity' from rights in her categorization. In doing this she is highlighting the large political theory literature that uses the term 'citizenship' to denote 'active engagement in the life of the political community', ${ }^{83}$ and she links it to civic republican theory and participatory democratic principles about an active, engaged citizenship. This idea revolves around the ideal political society where all citizens are encouraged to be 'good citizens'. It views political involvement in a polity as a positive normative ideal. However, in order to be an active citizen, one needs to have the political rights to do so, and this is where Mr Ame and his colleagues fell down in their claim to Australian citizenship.

The fact that the Australian Parliament denied the political rights normally linked to citizenship from Papuans - such as voting, jury service, and freedom of movement in and out of the mainland - meant that the High Court could determine they did not hold a 'real citizenship'. This largely tautological framing of citizenship (those who have citizenship rights are citizens and those who don't are not) gives enormous power to the state to manipulate membership of the community.

79 Linda Bosniak, 'Citizenship Denationalized' (2000) 7 Indiana Journal of Global Legal Studies 447, 463-464.

80 ibid 465.

81 As stated earlier, there is another story that parallels the PNG-Australia story that is closer to home: that of indigenous Australians and their claims to citizenship. See John Chesterman and Brian Galligan, Citizens Without Rights: Aborigines and Australian Citizenship (Cambridge University Press, 1997).

82 See Ame (2005) 222 CLR 439, 470 (Kirby J).

83 Linda Bosniak, 'Citizenship Denationalized' (2000) 7 Indiana Journal of Global Legal Studies 447, 470. 
For Papua New Guinea, the fact that Australia had narrowed the meaning of citizenship to enable it as a state to discriminate between Papuan Australian citizens and mainland Australian citizens was one of the drivers to be explicit about making citizenship more meaningful and 'equal' in the new state of Papua New Guinea. This resolve to use the term 'real citizenship' became a further reason for the High Court of Australia to deny Mr Ame and those like him any force to their claim of citizenship and any rights flowing from it.

For Mr Ame and those like him, any sense of connection to Australia from birth in Australian territory or sense of Australian identity from growing up in Australian territory, was not relevant to the High Court's conceptual framework. Bosniak's fourth categorization of citizenship as 'identity/solidarity' had no voice or outlet in this legal story. This understanding of citizenship is often referred to as the 'psychological dimension, that part of citizenship that describes the affective ties of identification and solidarity that we maintain with groups of other people around the world' ${ }^{84}$ This is where those Papuans born in Australian territory, with Australian birth certificates, had a feeling of citizenship that was not fully recognized by the state, ${ }^{85}$ even though the state had put out legal markers such as legal status and other attributes of citizenship to assist in creating that feeling and sense of connection.

The joint judgment of the majority in Ame does not take account of this aspect of citizenship — the fact that at least some Papuan Australians personally identified as Australian citizens. Perhaps this is because identity is too malleable, too fluid, too non-determinant, non-concrete and non-fixed as a concept for law, in this instance, to take hold of and use for assisting in the determination of disputes. Why did the fact that these Papuans were given no choice in determining their own citizenship identity, with the change over of sovereignty, not gain currency? And how does that sit with the fact that the legal status is also malleable, in that there is little to claim with it, that it can be easily changed and modified, while at the same time it has the potential for great aspirational value? While Kirby J in his separate opinion recognized some of the normative force of the applicant's claim, His Honour was swayed by the international context of the impugned law. The fact that similar measures had been part of other countries' experience of decolonisation assisted him in making his decision. Morevoer, the force of what the people of Papua New Guinea had been seeking to achieve when they

\footnotetext{
84 ibid 479.

85 This point is also made out strongly in another Papuan-Australian citizenship matter involving Susan Walsh that led to a special leave application in the High Court of Australia, prior to the Ame matter. See Kim Rubenstein, 'The Lottery of Citizenship: The Changing Significance of Birthplace, Territory and Residence to the Australian Membership Prize' (2005) 22(2) Law in Context 45.
} 
substituted full and effective citizenship of the newly unified and independent state for the clearly inferior citizenship that Australia had previously offered to Papuans were persuasive, in his view, against the applicant's case. ${ }^{86}$

This final point brings us back to the idea of 'thick' and 'thin' descriptions of citizenship. Conceiving of Australian citizenship solely as a matter of legal status results in a very 'thin', superficial account of what it means to be a citizen. Concentrating on the legal status of citizenship, and its legal incidents such as voting rights and rights of entry and residence, is clearly the method preferred by lawyers and courts called upon to determine whether a person is entitled to call themself an Australian citizen. However, the rules governing access to citizenship and likewise to the franchise or to rights of entry into Australia do not explain all of what it means, at a personal level, to be a citizen. Neither do they provide a complete explanation of the social significance of citizenship as a label denoting full and effective membership of a community. In general, a citizen is a person who is entitled to various social and political rights, including the right to vote and to enter and remain in Australia. So much is clear from the cases and statutes. However, for many people citizenship also connotes a sense of belonging, of identifying as a citizen of a particular nation (or of several nations), or as Bosniak puts it, a sense of 'solidarity' with a national community. Incorporating these facets of citizenship 'thickens' our description of a complex social, political and personal phenomenon.

\section{Conclusion}

Ame is an instance in which the High Court recognized what citizenship theorists have long argued - that citizenship can mean different things, and that to say that a person holds the formal legal status of citizen is only the beginning of an explanation of what their citizenship means. In that case, the Court inferred from the fact that Papuan-born Australian citizens did not possess the same political rights as Australian citizens in the States and internal Territories that their statutory citizenship was not real. It was taken to be so thin as to be defeasible. While the High Court was at pains to emphasise that what happened to $\mathrm{Mr}$ Ame and his fellow Papuans could not so easily happen to Australian citizens who do not live in an external Territory, this reasoning is premised on an understanding that for most of them, Australian citizenship carries with it a set of political and social rights that cannot easily be stripped away. 
This text taken from Law and Democracy: Contemporary questions, edited by Glenn Patmore and Kim Rubenstein, published 2014 by ANU Press, The Australian National University, Canberra, Australia. 